\title{
5 Protection of the fundamental rights of older adults - methodological perspective of administrative and legal research
}

\author{
Anna Szafranek
}

This chapter refers to the following research methods used in the gerontological research:

- photographic method,

- individual case studies as well as multiple case studies,

- autobiographical method,

- focused interviews,

- $\quad$ research using the International Older Persons' Human Rights Index (IOPHRI).

Methodological conclusions:

1 While carrying out administrative and legal research on older adults, special attention should be paid to proper conceptualization of research, specifically to the selection of indicators, the ways of measuring them as well as to defining basic notions.

2 Qualitative methods are usually used to study older adults, which is why these methods are also used in the research into protection of their rights. An especially adequate tool seems to be a multiple case study, also called multiplace qualitative research.

3 As a research technique (in administrative and legal research) it is worth using an indepth problem-centered interview and, as a research tool, a semi-structured interview.

4 An individual narrative in comparison with other research methods gives older adults a sense of security, and for lonely senior citizens is often one of the few forms of contacting the outside world, while in the case of research, for example, concerning violence, may serve as an informal therapy.

5 In selecting a research sample, it should be strongly emphasized that older adults (especially when it concerns today's generation of senior citizens, who have survived the war, the post-war period and communist rule - the example of East Europe) are one of the most heterogeneous groups as far as education is concerned. This means that improper choice of research sample or omitting this fact in the results analysis may be a misuse and may result in methodological mistakes, which would in turn lead to erroneous conclusions. In order to avoid the mistakes described above, cohort studies may be considered (taking into account appropriate criteria of selection).

\section{Introduction}

Contemporary society is characterized by global demographic dynamics, which bring about the necessity to adjust social policy and laws to the needs and expectations of older adults, whose number is systematically increasing. The ageing of society has not only demographical impact but also social, cultural, economic and legal impact. Therefore, gerontology as a science should be perceived from an interdisciplinary perspective and also from 
the point of view of gerontological research (Kijak and Szarota, 2013, p. 6). Thereby, one of the characteristics of contemporary science, including methodology, is interdisciplinarity. This is proven not only by plenty of national research but also reports from international research.

It needs to be emphasized that gerontology is defined within the category of interdisciplinary science of ageing and old age (Polak et al., 2007, pp. 51-53), which focuses on analyzing ageing and old age while taking into account optimal living conditions of older adults (Orzechowska, 1999) (in the demographic, social, economic, medical and legal aspects). The need for the analysis of these aspects of gerontology is strongly connected with the phenomenon of ageing societies, not only in Poland and Europe but also around the world. According to the forecasts, in 2050 every fifth inhabitant of Earth will be aged 60 years or more, while in 2150 it will concern every third person (Malec, 2008, p. 130) It needs to be mentioned that in the light of the data collected by the Polish Central Statistical Office (GUS), in 2015 in Poland the average life expectancy was 73.6 years for men and 81.6 years for women. In comparison with the data from the early 1990s, the female life expectancy increased by circa seven years, with six years for men; while in comparison with the year 2000 , both men and women lived approximately four years longer. It is also forecast that the population of centenarians and people over 100 years will gradually increase (http://stat.gov. pl/infografiki-widzety/infografiki/infografika-osoby-starsze-w-wieku-100,41,1.html). Therefore, the need will arise to adjust current legislation and introduce new systemic solutions, for example in the field of social care and legislation concerning older adults. For the implementation of the abovementioned (example) regulations to be successful, it is necessary to conduct interdisciplinary research, which will not only diagnose the current situation but also for instance evaluate new pilotage legal solutions. Although so far interdisciplinarity has mainly been characteristic of medical, health and economic sciences, in view of the demographic changes and increasing social participation of older adults, it seems absolutely essential to develop the methodology of administrative and legal gerontological research. The aim of this chapter is to present the methodological bases in this area, good methodological practices in administrative and legal research concerning the legal rights of older adults, as well as the demands and recommendations concerning the implementation of such research.

\section{The basics and new perspectives of gerontological research ${ }^{1}$}

The literature on the subject emphasizes the fact that gerontology as a science has both learning and practical goals. Thereby, it studies the practical functioning of older adults in various aspects of social life, while remembering that the results should be used, and in many cases are already used, to create favorable living conditions and to solve multiple problems connected with ageing and old age from the social, economic, demographic, medical, educational and legal perspective (Orzechowska, 1999; Halicka and Halicki, 2014, pp. 139-156). Moreover, some researchers stress that gerontological research may not be separated from theory as this may result in methodological flaws, while others contend that the research findings may not be analyzed without taking into consideration theoretical bases (which are built around empiricism) (Hendricks, Applebaum and Kunkel, 2010, pp. 284-293).

The international literature on the subject lists the methods which are or should be used in gerontology more than in other disciplines. This suggests that gerontology as a science has partly developed a specific methodological approach. A very good example is "the photographic method", which was used in the research into the perception of ageing in 
rural areas. It was additionally enriched by observation and in-depth interviews with individuals (Magilvy et al., 1992, pp. 253-257). It has also been noted that it would be advisable to apply focused research, for example research into living in social care homes carried out among their residents (Kydd et al., 2018, p. 232). However, when it comes to protecting the fundamental rights of older adults (which may be easily considered a sensitive issue), this method will not be applicable (for example due to the presence of strangers during focused interviews).

A crucial role in the research conducted among older adults is played by narrative (used in qualitative research). The narrative perspective is applied for example to research into the anthropology of ageing and the culture of ageing (Perkinson and Solimeo, 2014, pp. 101-107). Closely related to narrative is the autobiographical method (used especially in pedagogical research) (Duccio, 1999) and individual case studies as well as multiple case studies (Pilch, 2010). ${ }^{2}$ Analysis of the literature on gerontological studies reveals that researchers use qualitative research more willingly than quantitative (with an exception of longitudinal research) (Putnam, 2018, pp. 127-128), ${ }^{3}$ for instance, when analyzing the access of older adults to rural health services, researchers in New Zealand used methods which they described as a qualitative narrative gerontological approach, using semistructured interviews (Neville et al., 2019, pp. 1-7).

In gerontological research concerning medical aspects, the object of the analysis was the purposefulness of using standardized questionnaires, pointing to their numerous advantages but also drawbacks (Bravell, Johansson and Finkel, 2018, p. 149). Such questionnaires cannot be applied to legal research as medical research is mostly based on facts (where completing standardized questionnaires basically does not pose serious problems), while legal research is based on opinions.

Nevertheless, it is worth remembering that in gerontology, as in other disciplines, flexibility and an interdisciplinary approach to research are crucial. That is because, depending on the research topic, various approaches and analyses can be combined, which gives the possibility of studying a complex problem from different perspectives (Cornwell, Marcum and Silverstein, 2015, pp. 87-90). Another widely discussed attribute in the area of designing and conducting gerontological research is transparency (Brown and Allison, 2018, p. 808). Putnam, apart from transparency in gerontological research, emphasizes the need for translating research results into practical solutions (2018, pp. 127-128). For example, the so-called method of deliberative dialogues is interesting. This bridges gerontological research with policy and practice, when integration of approaches and activities of various groups (academic circles, practitioners and decision-makers) enables sharing of knowledge and experience, and that means putting theory into practice - e.g., Canadian research into housing provision to senior citizens (Canham, Wada and Schwartz, 2017, p. 1076-1077).

Summing up, the following trends are discernible in contemporary gerontological research: interdisciplinarity, bridging theoretical, empirical and applicational approaches, as well as conducting research on the basis of theories which are especially selected and adjusted to the subject and goal of research - all these assumptions are met by administrative and legal research into the protection of fundamental rights of older adults.

\section{Methodological connections and barriers between sociology and law}

Methodological connections between sociology and law were indicated as long ago as in the works of Emile Durkheim, who said that law is a social fact exterior to the individual person and inseparably connected with an external constraint (2000, pp. 27-33). Sociological as well 
as legal and administrative sciences require precision; for example, in defining phenomena or in solving problems. Therefore, it seems right to refer to Durkheim's suggestion that all the above-mentioned sciences should "study only a group of phenomena previously defined by their common external characteristics and by this encompass in their studies all the phenomena which refer to the definition itself' $(2000$, p. 65). This quotation clearly emphasizes the necessity of applying precision to scientific (sociological and legal) research, as both these disciplines require it; however, in different dimensions. The aim of administrative and legal research encompasses both questions stemming from legal sciences and concerning for instance the sources of law, legal systems, the effectiveness of specific norms, but also questions arising from the point of view of social sciences devoted to the influence of specific regulations or norms on community life (Frieske, 2001, p. 8).

Although legal (or administrative and legal) research uses methods developed in sociology, in many cases they require certain modification (Ziembiński, 1975). Some of the social research methods can be fully applied to research on law, some only partially, and some are not applicable at all (Pieniążek and Stefaniuk, 2014, p. 122). It needs to be stressed that sociological and legal research is not possible in isolation from the current social, political, religious, ideological and economic situation (depending on the selected subject matter). Moreover, law is an instrument of the authority of the state, which is why the literature on the subject contends that. in the case of persons who are knowledgeable about the current legal system or clearly favor it, the questions about their opinion on the current system may raise suspicion as to the aim of the research as well as cause a sense of insecurity in respondents (Pieniążek and Stefaniuk, 2014, p. 122). ${ }^{4}$

A sense of insecurity may also appear in older adults during research concerning their fundamental rights. In a way, even a question: "Name your fundamental rights" may raise fear as respondents may not be aware of their rights. Consequently, they will possibly perceive such a question as an accusation of ignorance and as a result will resort to oversimplification (what is the aim of observing one's rights and extending their scope if older persons - the beneficiaries - have neither the knowledge about them nor the awareness of how to exercise them). Therefore, a sense of insecurity may be one of the obstacles to applying sociological methods to legal research (Pieniążek and Stefaniuk, 2014, pp. 122-123), including that concerning the protection of the rights of older adults. It seems that to some extent the problem may be eradicated, for instance by making every effort to keep questions in the research tool comprehensible (without such basic methodological mistakes as multiplication, false assumptions, questions raising insecurity in respondents) (Lutyńska, 1984). ${ }^{5}$

Another difficulty, especially in the case of older adults, is a specific intellectual tool used when discussing law. Some of the terminology concerning the protection of fundamental rights of older adults may not be understood or may require explanation and clarification on the part of the researcher. Therefore, although from the methodological point of view it may seem obvious, it is not always observed: conducting research among older adults without prior pilotage is a mistaken approach. In consequence, it appears that qualitative methods enabling immediate contact with respondents are more adequate for research into the protection of fundamental rights of older adults (which is going to be discussed below).

\section{Operationalization of basic notions}

A response to the demographic changes is the national administration performing different public tasks in the field of social care (Pszczyński, 2014, pp. 83-96) (including the rights 
of older adults). Consequently, research should include a legal perspective (concerning, for instance, research into the implementation and effectiveness of specific acts of law) and an administrative perspective (concerning, for instance, research into the effectiveness of the actions taken by law enforcement agencies), which are closely related. Moreover, the Center for the Study of Ageing points to the need for analysis of the link between institutional factors (a reference to administrative research) and socio-economic factors in the study of ageing (www.rand.org/well-being/social-and-behavioral-policy/centers/ageing/ research.html).

Since this chapter concerns the methodological perspective, it does not discuss national or international documents dealing with the protection of rights of older adults; ${ }^{6}$ it only quotes some of them in order to exemplify the rights of older adults which could be subject to analysis. It should be mentioned that a basic document containing a detailed catalog of human rights (to which every person is entitled, irrespective of their age) is the European Convention on Human Rights adopted in Rome on 4 November 1950. However, as Barbara Mikołajczyk notes, a real breakthrough came with an international document called the United Nations Principles for Older Persons adopted in 1991 because of its comprehensive approach to the situation of the elderly. The principles, which are guidelines for each country, are divided into the following groups: independence, participation, care, selffulfillment and dignity (Mikołajczyk, 2012, p. 101). ${ }^{7}$ The literature on the subject, however, points out that international protection of the rights of older adults does not receive enough attention and a comprehensive tool to help them and protect their rights has not yet been devised (Tonolo, 2018, pp. 107-120).

Bearing in mind the United Nations Principles for Older Persons, a group of Polish practitioners led by the Citizens' Rights Ombudsman prepared a human rights handbook addressed to older adults, which focused on the following four areas of crucial practical importance for them: the right to social welfare, the right to healthcare, the prohibition of torture and inhuman or degrading treatment and the right to respect for private and family life, home and correspondence (Bienasz et al., 2012, p. 18). The groups considered by the authors are tantamount to the UN guidelines for older adults.

In conclusion, one must refer to the thought of B. Mikołaczyk, who clearly stresses that global ageing is a huge social challenge, and to international opinion on the importance of protecting the rights of older adults (including the right to healthcare, which is tantamount to the area pointed to by the Polish Citizens' Rights Ombudsman) ${ }^{8}$ Therefore, research into the protection of fundamental rights of older adults is urgently required, and its conclusions should yield improvement in the effectiveness of current legislation (including that concerning its implementation) (Mikołajczyk, 2019 pp. 1611-1638). However, this will be impossible without developing methodological bases for the research. Additionally, when looking into the literature on the subject of the rights of older adults, a deficit in research in this field is visible, although there are analyses of national or international legislation protecting the rights of the elderly. Moreover, while there are a lot of analyses of local/national legislation concerning the rights of older persons, similar research conducted internationally is still lacking (Doron, Cox and Spanier, 2019, pp. 625-634).

\section{Good practices in the methodology of administrative and legal research into the protection of fundamental rights of older adults}

As suggested above, law, as one of the social sciences, benefits from the achievements in sociology in its methodology. On this basis, it constructs elaborate research methods of 
analyzing structures, opinions or specific activities (legal research) as well as institutions (administrative research). Conducting administrative and legal research together, as a matter of principle, means they should complement each other and achieve a broader picture of the phenomenon in question.

Administrative and legal research (similar to other social research) may not be conducted in isolation from the political, economic and social situation in the research area. ${ }^{9}$ That is why it is complicated to develop a universal research tool or to list conditions for selecting a research sample which could be applied internationally (without additional modifications). The International Older Persons' Human Rights Index (IOPHRI) is seeking to bridge this gap - using the research tool in question, ${ }^{10}$ the research compared the legislation in six countries representing all the continents with their geographical, legal and cultural diversity, i.e., the United States, Ireland, South Africa, India, Chile and Australia (after having tested the tool in Austria). The authors testing the tool asked a crucial question: "Can the human rights of older persons be measured and compared?" (Doron, Cox and Spanier, 2019, p. 631). They also indicated important challenges in conducting research concerning older adults such as: (1) whether the research is conducted in federal countries or in not federal countries, (2) whether the research into the protection of fundamental rights of older adults is carried out with reference to legal regulations contained in specific acts of law, practical implementation of these principles "in real life" or the law laid out by courts, (3) the social and cultural differences between the countries and the social impact of law. The authors clearly concluded that the index requires more work, taking into account a broader social context of each country; however, a milestone achieved was proving the advisability of analyzing the protection of the older persons' rights. What's more, the link between the theoretical aspect of human rights (what the letter of the law says) and the opinions of senior citizens also calls for in-depth research (Doron, Cox and Spanier, 2019, pp. 631-633).

Furthermore, while referring to past research concerning protection of fundamental rights of older adults and applying good practices used in methodology, it is possible to formulate universal guidelines, which may be followed in conducting research in the subject area. This is presented below.

While carrying out administrative and legal research on older adults, special attention should be paid to proper conceptualization of research, specifically to the selection of indicators, the ways of measuring them as well as to defining basic notions. As C. FranfortNachmias and D. Nachmias stress, the key issue is to insure common intelligible language of communication between researchers and respondents $(2001$, p. 44$)$. When it comes to research into the fundamental rights of older adults, the researcher needs to insure that respondents understand what the notion "fundamental rights" covers, which rights are being analyzed (if the analysis concerns their selection) and what the aim of this analysis is. According to E. Babbie, "an indicator is a sign of presence or absence of the concept being studied" (2007, p. 144). As an example, Babbie analyzes the notion of compassion, where he distinguishes such compassion indicators as visiting children's hospitals at Christmas or putting fledglings back into their nests (however, it is the researcher who forms a list of indicators based on his or her experience and the literature on the subject) (Babbie, 2007, p. 144). As for the fundamental rights of older adults, indicators may be defined by referring to the level of implementation of specific rights deriving from current acts of law.

Another pivotal issue is the selection of a research sample. It needs to be strongly emphasized that older adults (especially when it concerns today's generation of senior citizens, who have survived the war, the post-war period and communist rule) are one of 
the most heterogeneous groups as far as education is concerned. This means that an improper choice of a research sample or omitting this fact in the results analysis may result in methodological mistakes, which would in turn lead to erroneous conclusions. For instance, when studying old-age residents of social care homes and Third Age University students, the analysis of the results obtained from the perspective of one group only will most probably lead to mistaken conclusions. Although both groups consist of older adults (who thus satisfy the condition for being included in the research group), they may differ significantly when it comes to education. The Third Age University students as a rule will be better educated (which means more extensive knowledge and awareness of their rights and their protection) than social care home residents. In consequence, a statistical picture of the results obtained (for instance: high awareness of their rights among respondents) will be falsified - research will misinterpret the sources (research material obtained).

In order to avoid the mistakes described above, cohort studies may be considered ${ }^{11}$ (for example, among older adults who within the last 12 months at least three times have attended Third Age University classes, or among older persons who within the last 12 months have reported infringement of their rights to the Polish Citizens' Rights Ombudsman).

As mentioned above, qualitative methods are usually used to study older adults, which is why these methods are also used in research into protection of their rights. An especially adequate tool seems to be a multiple case study, which allows for theoretical perception of the research problem as a group thanks to the analysis of specific cases. Robert Herriot and William Firestone call such a study multiplace qualitative research (Pawłowska, 2012, p. 270). It may be added that a useful technique could be an in-depth problem centered interview (Witzel, 2000). However, the most commonly used research tool (a conclusion derived from the articles on the subject) is a semi-structured interview.

An individual narrative in comparison with other research methods gives older adults a sense of security, and for lonely senior citizens is often one of the few forms of contacting the outside world, while in the case of research, for example, concerning violence, may serve as an informal therapy. ${ }^{12}$ As S.E. Chase points out, a narrative is

a retrospective meaning creation - shaping past events or ordering them. A narrative is also comprehension of one's own actions and the actions of others.... Differently from chronology, which places events in time, a narrative conveys the point of view of a narrator.... Apart from describing what happened, narratives express emotions, thoughts and interpretations.

(2009, pp. 24-25)

Narratives enable each of the respondents to look at the subject matter subjectively, and discern similarities and differences in judgments and opinions (Chase, 2009, p. 25). This in turn will help to formulate recommendations concerning improvement in exercising specific statutory rights of older adults (this refers to ensuring applicability of good practices in conducting research). Moreover, as mentioned above, legal topics and terminology may be incomprehensible to old-age respondents. In such cases, researchers may adopt the role of an auxiliary voice - which is characteristic of Latino-American narratives (as opposed to the authoritative voice of the researcher (Chase, 2009, pp. 37-39), which may raise a sense of insecurity in old-age respondents, which is why it should be used only when justified and with utmost care), who will explain complex notions and at the same time focus on the narrator and his or her prominent role in the interview. Such an approach to respondents and the subject matter itself creates conditions for obtaining satisfactory results. 


\section{Conclusion}

Conducting research into protection of fundamental rights of older adults is not the easiest of endeavors. Considering the need for adjusting research tools or selecting research samples to current social, cultural and legal conditions of a given country, it is difficult to formulate unequivocal guidelines for conducting such research. However, after analyzing available research, the literature on the subject and one's own experience as a researcher, it is possible to draw up a list of recommendations, which will facilitate construction of the research process in the present subject matter. Thus, the following conclusions can be drawn:

1 Conducting research (especially administrative and legal) requires an interdisciplinary approach and reference to specific theoretical approaches, which are crucial in the process of conceptualization, especially when specifying indicators.

2 Legal and administrative research concerning protection of fundamental rights of older adults should be designed while bearing in mind its application, i.e., putting the solutions into practice.

3 Legal and administrative research poses questions rooted in legal sciences, for instance those concerning the sources of law, legal systems, the effectiveness of specific norms, but also in social sciences focused on the impact of specific regulations or norms on collective life (Frieske, 2001, p. 8).

4 Administrative and legal research is not possible in isolation from current social, political, religious, ideological and economic circumstances (depending on the selected subject matter).

5 It appears that qualitative methods enabling immediate contact with respondents are more adequate for research into the protection of fundamental rights of older adults. An especially useful tool seems to be a multiple case study, which allows for theoretical perception of the research problem as a group thanks to the analysis of specific cases.

6 Research concerning protection of fundamental rights of older adults may be perceived as a sensitive issue, which is why it should be carried out with the use of an individual interview (focused research or diagnostic poll are not recommended), which allows for avoiding mistakes connected with respondents feeling insecure or an incomprehensible specialist intellectual tool.

\section{Notes}

1 For the purpose of this chapter, the selected perspectives on gerontological research were taken into account, which are characterized by an interdisciplinary and multiperspective approach as well as those which are significant for administrative and legal research on protection of the fundamental rights of older adults.

2 Gerontological research with the use of narratives provided by older adults was conducted as part of pedagogical research by, inter alia, J. Halicki (2010) and J. Maćkowicz (2015), or the sociological research of M. Halicka and her group (for example: Halicka, 2014; Halicka et al., 2017, 2016) and A. Szafranek (for example: Szafranek, 2014, 2016).

3 An example of longitudinal research is the research on the impact of sleep disturbance on depressive states, carried out among 3108 UK residents aged 65 years and over and 7527 Japan residents aged 65 years and over - see Cable et al. (2017) and see a list of other longitudinal research, available at: www.rand.org/well-being/social-and-behavioral-policy/centers/ageing/resources.html [Accessed 9 August 2019]. 
4 It needs to be emphasized, though, that the authors refer to questioning a group of business people on tax law - the questions concerning the purpose of specific regulations may raise fear of detecting tax fraud.

$5 \mathrm{~K}$. Lutyńska contends that one of the most common mistakes in designing research tools is formulating questions in a way that raises the feelings of insecurity in respondents.

6 The documents concerning protection of the rights of older adults are discussed in detail in the monograph by Mikołajczyk (2012) as well as in the article by Mégret (2011).

7 United Nations Principles for Older Persons (Zasady dziatania ONZ na rzecz osób starszych) are available at www.tus.org.pl/uploads/dokumenty/zasady_dzialania_onz_na_rzecz_osob_starszych. pdf [Accessed 7 August 2019].

8 In Poland, there is the Committee for Older Persons of the Citizens' Rights Ombudsman consisting of the representatives of various academic circles, also sociology and law, which proves the need for interdisciplinary cooperation in gerontological research.

9 A good example of linking research with social and political background is Africa, where in 2016 the African Union adopted the Protocol to the African Charter on Human and Peoples' Rights on the Rights of Older Persons in Africa - which undoubtedly should be considered while designing research in the subject area. See: Chirwa and Rushwaya (2019).

10 The research tool is described in detail together with its application and findings in: Doron, Cox and Spanier (2019).

11 Detailed information on designing cohort studies among older adults can be found for example in the article by Kingston and Jagger (2018).

12 The conclusion of the Author, who in 2010-2011 carried out in-depth interviews among the residents of Podlasie social care homes concerning institutional violence, and in 2016 interviews with practitioners working with those who suffer domestic violence.

\section{References}

Babbie, E. (2007). Badania społeczne w praktyce. Warszawa: PWN.

Bienasz, D., Matejczuk, G., Szczeblewska, H. and Zima-Parjaszewska, M. (2012). Prawa człowieka: Poradnik dla osób starszych. Warszawa: Rzecznika Praw Obywatelskich.

Bravell, M.E., Johansson, L. and Finkel, D. (2018). Using national quality registries in gerontological research: pros and cons. Innovation in Ageing, 2(1), 149.

Brown, A.W. and Allison, D. (2018). Interest group session - measurement, statistics, and research design: strengthening ageing research: experiences with rigor, reproducibility and transparency. Innovation in Ageing, 2(1), 808.

Cable, N., Chandola, T., Aida, J., Sekine, M. and Netuveli, G. (2017). Can sleep disturbance influence changes in mental health status? Longitudinal research evidence from ageing studies in England and Japan. Sleep Medicine, 30, 216-221.

Canham, S.L., Wada, M. and Schwartz, A.J. (2017). Deliberative dialogues: opportunities for bridging gerontological research with policy and practice. Innovation in Ageing, 1(1), 1076-1077.

Chase, S.E. (2009). Wywiad narracyjny: Wielość perspektyw, podejść, głosów. In: N.K. Denzin and Y.S. Lincoln (eds), Metody badań jakościowych. Vol. 2. Warszawa: PWN.

Chirwa, D.M. and Rushwaya, C.I. (2019). Guarding the guardians: a critical appraisal of the protocol to the African Charter on the Rights of Older Persons in Africa. Human Rights Law Review, 19(1), 53-82.

Cornwell, B., Marcum, C. and Silverstein, M. (2015). The social network approach in gerontological research. Journals of Gerontology: Series B, 70(1), 87-90.

Doron, I., Cox, C. and Spanier, B. (2019). Comparing older persons' human rights: exploratory study of the International Older Persons' Human Rights Index (IOPHRI). The Gerontologist, 59(4), 625-634.

Duccio, D. (1999). Zabawa na tle życia: Gra autobiograficzna w edukacji dorostych. Kraków: Impuls.

Durkheim, E. (2000). Zasady metody socjologicznej. Warszawa: Biblioteka Socjologiczna, PWN.

Franfort-Nachmias, C. and Nachmias, D. (2001). Metody badawcze w naukach społecznych. Poznań: Zysk i S-ka. 
Frieske, K. (2001). Socjologia prawa. Poznań: Polskie Wydawnictwo Prawnicze Iuris.

Halicka, M. (2014). Satysfakcja życiowa ludzi starych. Białystok: Akademia Medyczna Białystok.

Halicka, M. and Halicki, J. (2014). Gerontologia społeczna a socjologia starzenia się i starościpoznawcza tożsamość, trendy, perspektywy. In: M. Skrzypek (ed.), Podstawy interdyscyplinarności w naukach o zdrowiu. Lublin: Wydawnictwo KUL.

Halicka, M., Halicki, J., Szafranek, A. and Kramkowska, E. (2016). Choroba jako czynnik sprzyjający przemocy wobec zamężnych kobiet w starszym wieku. Gerontologia Polska, 24(3), 184-191.

Halicka, M., Halicki, J., Szafranek, A. and Kramkowska, E. (2017). Kobiety doświadczajace przemocy w rodzinie i ich ochrona. Białystok: UwB.

Halicki, J. (2010). Obrazy starości: Rysowane przė̇yciami seniorów. Białystok: UwB.

Hendricks, J., Applebaum, R. and Kunkel, S. (2010). A world apart? Bridging the gap between theory and applied social gerontology. The Gerontologist, 50(3), 284-293.

Kijak, R.J. and Szarota, Z. (2013). Starość: Między diagnozq a działaniem. Warszawa: Centrum Rozwoju Zasobów Ludzkich.

Kingston, A. and Jagger, C. (2018). Review of methodologies of cohort studies of older people. Age and Ageing, 47, 215-219.

Kydd, A.B., Smith, S., King, L., Gentleman, M., Walsch, N., Head, K. and Smart, F. (2018). Engaging students as co-researchers to conduct focus groups with older people. Innovation in Ageing, 2, 232.

Lutyńska, K. (1984). Wywiad kwestionariuszowy: Przygotowanie i sprawdzenie narzędzia badawczego. Wrocław: Ossolineum.

Maćkowicz, J. (2015). Osoby starsze jako ofiary przemocy domowej: Ujęcie wiktymologiczne. Kraków: Impuls.

Magilvy, J.K., Congdon, J.G., Nelson, J.P. and Craig, C. (1992). Visions of rural ageing: use of photographic method in gerontological research. The Gerontologist, 32(2), 253-257.

Malec, M. (2008). Czy osoby starsze potrzebują nauczyciela? W poszukiwaniu geragoga. In: A. Fabiś (ed.), Aktywność społeczna, kulturalna i oświatowa seniorów. Bielsko-Biała: Wyższa Szkoła Administracji.

Mégret, F. (2011). The human rights of older persons: a growing challenge. Human Rights Law Review, 11(1), 37-66.

Mikołajczyk, B. (2012). Międzynarodowa ochrona praw osób starszych. Warszawa: Wolters Kluwer.

Mikołajczyk, B. (2019). Older persons' right to health: a challenge to international law. Ageing \& Society, 39(8), 1611-1638.

Neville, S., Napier, S., Adams, J. and Shannon, K. (2019). Accessing rural health services: results from a qualitative narrative gerontological study. Australasian Journal of Ageing. doi.org/10.1111/ ajag.12694.

Orzechowska, G. (1999). Aktualne problemy gerontologii społecznej. Olsztyn: Wyższa Szkoła Pedagogiczna.

Pawłowska, B. (2012). Studium przypadku. In: K.T. Konecki and P. Chomczyński (eds), Stownik socjologii jakościowej. Warszawa: Difin.

Perkinson, M.A. and Solimeo, S.L. (2014). Ageing in cultural context and as narrative process: conceptual foundations of the anthropology of ageing as reflected in the works of Margaret Clark and Sharon Kaufman. The Gerontologist, 54(1), 101-107.

Pieniążek, A. and Stefaniuk, M. (2014). Socjologia prawa: Zarys wykładu. Warszawa: Wolters Kluwer.

Pilch, T. (2010). Zasady badań pedagogicznych: strategie ilościowe i jakościowe. Warszawa: “Żak”.

Polak, A., Porzych, K., Kędziora-Kornatowska, K., Motyl, J., Porzych, M., Słupski, M. and Lackowska, D. (2007). Poznawczy i praktyczny wymiar gerontologii: interdyscyplinarnej nauki o starzeniu się i starości. Gerontologia Polska, 15(3), 51-53.

Pszczyński, M. (2014). Destynariusz domu pomocy społecznej w podeszłym wieku: Aspekty administracyjno-prawne. In: A. Wilk and M. Gołowkin-Hudała (eds), Prawne aspekty starości. Warszawa: Difin. 
Putnam, M. (2018). Journal of Gerontological Social Work: standards for reporting research. Journal of Gerontological Social Work, 61(2), 127-128.

Szafranek, A. (2014). Retired elderly in a care institution: the process of adaptation to life in a social care home. Contributions to Humanities, 13(4), 199-214.

Szafranek, A. (2016). Sytuacja konfliktu i przemocy w opinii pracowników i mieszkańców podlaskich domów pomocy społecznej. Gerontologia Polska, 24(3), 176-183.

Tonolo, S. (2018). International human rights law and the protection of the elderly in Europe. Medicine, Law \& Society, 11(2), 107-120.

Witzel, A. (2000). The problem centered interview. Forum: Qualitative Socialforschung/Forum: Qualitative Social Research, 1(1). Available at: www.qualitative-research.net/index.php/fqs/ article/view/1132/2521 [Accessed 15 August 2019].

Ziembiński, Z. (1975). Socjologia prawa jako nauka prawna. Poznań: Państwowe Wydawnictwo Naukowe. 